\title{
SPONTANEOUS EUROIZATION IN THE CZECH REPUBLIC (is it a problem and why not?)
}

\author{
Martina HORNÍKOVÁ, Jaromír HURNÍK, * Viktor KOTLÁN**
}

\begin{abstract}
:
The paper offers a preliminary analysis of possible spontaneous euroization in the Czech economy. After a brief general introduction of the issue of currency substitution it specifically discusses two things. First, the transmission channels of potential spontaneous euroization, through which the process could possibly complicate the implementation of domestic monetary policy. Second, it analyses the degree of euroization. Among the transmission channels, attention is paid to interest rate and exchange rate channels. The circumstances under which the transmission would be sub-optimal are discussed. Besides the impact on the monetary policy transmission, another risk of progressive spontaneous euroization is seen in the shift of the exchange rate risk from bigger to smaller enterprises in the economy. The available data do not allow a precise measurement of the degree of euroization. Nevertheless, both the ratio of euro-denominated over koruna-denominated deposits and the CNB's survey in 2003 suggest that euroization is not an obstacle for the Czech monetary policy at the moment.
\end{abstract}

Keywords: euroization, dollarization, monetary policy, transmission mechanism, currency, currency substitution

JEL Classification: E42, E52, F15, F42

\section{Introduction}

Euroization $^{1)}$ is a process of substituting a foreign currency for a domestic one to fulfil the essential functions of money as a medium of exchange (currency substi-

*) Czech National Bank, Na Př́íkopě 28, CZ - 11503 Prague 1 (e-mail: martina.hornikova@ @ cnb.cz; jaromir.hurnik@cnb.cz).

${ }^{\star *}$ ) Czech Saving Bank, Na Perštýně 1, CZ - 11398 Prague 1 (e-mail: vkotlan@ @ csas.cz).

1) Euroization is often called dollarization due to the origin of currency / asset substitution in South America. 
tution) and as a store of value (asset substitution). There are two forms of euroization - the official and the unofficial one. The first case, the official euroization, is a more proper definition according to which the euroisation is a form of official currency substitution where a reserve currency replaces the domestic legal tender. In such a case a country adopts de jure the currency of a foreign country to replace its domestic currency fully. Then the foreign currency has all the meanings of money and happens to be the authorized transaction medium, the store of value and the unit of account. It is generally regarded as the hardest form of pegged exchange rate regime, one that is more difficult to reverse than a currency board.

The official euroization ${ }^{2)}$ is not a pressing concern for the Czech Republic. However, euroization can take a spontaneous form as well. This is referred to as unofficial euroization. The process reflects a situation of firms and individuals spontaneously and voluntarily substituting a foreign currency for a domestic one as a means of payment (leading to a currency substitution) and/or choosing to hold foreign rather than domestic denominated monetary assets as a store of value (leading to an asset substitution).

The structure of this note is the following. First, the issue of euroization is explained, both the official and spontaneous forms. Second, the channels through which euroization may complicate the conduct of domestic monetary policy are discussed in a rather general manner. The focus lies in the challenges the euroization possess for the transmission of policy actions, although the impact on the transfer of currency risk in the economy is also briefly discussed. Third, the degree of euroization in the Czech economy is assessed using statistical data and survey results. The note ends with several concluding policy remarks.

\section{Euroization}

The discussion of the costs and benefits of abandoning the national currency in favour of the dollar or the euro has been taking place in many countries over the past two decades. This debate is especially effective in small open economies that are highly connected via the foreign trade with the European Union (in case of euroization) or with the United States (in case of dollarization). It is also a frequent point in discussions in the economies that have acceded the European Union recently under the obligation to join the monetary union in the future.

There are basically two ways how a foreign currency could be adopted instead of the domestic one. Either the country could adopt (let's say) the euro unilaterally or by prior arrangement with the given institution (in this case the European Central Bank - ECB or the European Commission). The latter is termed "consensual euroization", Meade et al. (2002). In this case, the euro would circulate in parallel to the domestic currency, or perhaps replace it altogether. In connection with the processes laid down for the EU Member States not participating in the euro area, this action would require authorities to fix the value of the domestic currency in terms of the euro, rather than participating in the ERM II target band arrangement for two years before entering the euro area.

2) For a detailed discussion on the topic of both the official and unofficial currency substitution see the papers presented at the Croatian National Bank's conference on Monetary Policy and Currency Substitution in the Emerging Markets (http://www.hnb.hr/dub-konf/8-konferencija-radovi/mazzaferro-thimann-winkler.pdf). For a discussion on official currency substitution (unilateral euroization) in the European countries see Bratkowski, Rostowski (2000). 
Euroization is not particularly new. Such an official currency substitution has become known as "dollarization" even if the currency chosen to replace the domestic currency is the euro or some reserve currency other than the US dollar. Schemes of this kind, familiar from Hong-Kong or Argentina, have been introduced recently in several transition economies. Nowadays, currency boards can be found in Estonia, Lithuania (together with ERM II participation), Bulgaria, Bosnia and Herzegovina, and the euro as a legal tender in Kosovo and Montenegro. Euroization schemes have been discussed also in Poland and Bulgaria; prospective euroization has been advocated for some post-Yugoslav Republics. ${ }^{3)}$

Several econometric studies have shown that hard pegs such as currency boards lead to better inflation performance. In one of these, by Ghosh et al. (2002), the authors find that, keeping other factors constant, inflation is $10.5 \%$ per year lower under a hard peg than under a floating exchange rate. More than one half of these, $5.5 \%$ represents the credibility gain associated with the hard peg regime, and the remaining $4.5 \%$ derives from lower money growth under the pegged regime.

In the best circumstances, euroization eliminates currency risk and possibly reduces default risk. The extent of these gains depends, of course, on how irreversible this substitution is perceived to be. Ideally, credibility gains from institutions' substitution will substantially narrow the spread on euro/dollar liabilities issued by the euroizing/dollarizing country relative to those issued by the respective foreign central bank, producing lower domestic interest rates.

Nevertheless, to follow the process of euroization successfully, other economic policies must be appropriate. In particular, euroization is a commitment by the monetary authority only and does not guarantee a responsible fiscal policy. Over the short-term, a lax fiscal policy can erode the credibility gain from such a currency substitution by putting upward pressure on domestic interest rates. Over the longer term, excessive deficits may undermine the monetary regime itself, by raising the incentive to monetize government debt.

In practice and as briefly mentioned above, there are more ways to adopt the foreign currency. On the one hand, unilateral dollarization or euroization, i. e. the country that is adopting the reserve currency does not require the agreement of the foreign issuer. On the other hand, broader forms of dollarization or euroization involve some set of on-going obligations for the issuer of the reserve currency and thus require mutual agreement by the two countries to a treaty or bilateral arrangement. This agreement could consider such issues as sharing of seigniorage revenue to fund a lender of the last resort facility. Finally, the most cooperative form of arrangement is a monetary union such as the euro area, in which participating countries share a currency and decision-making power. If such a currency substitution is to provide major credibility gains, it must be widely viewed as irreversible, as an irrevocable commitment to replace the domestic legal tender with the reserve currency.

As mentioned at the beginning of this chapter, some authors have advocated early euroization in the new EU Member States as an interim exchange rate arrangement during the transition to the EMU. A target band system, they argue, is crisis-prone and euroization would be the best regime to forestall a speculative attack. European officials do not see the ERM II as crisis-prone because of the wide bands around the central rate.

The unofficial (the so-called de facto) euroization is typically a response of economic agents to a loss of confidence in their domestic currency, often resulting from

3) A short summary on the issue of currency substitution in the European economies can be found in Nuti (2002). 
episodes of inflation or currency devaluation. It can be also related to a growth of unrecorded economic activities in which a foreign currency is often the preferred medium of exchange. Nevertheless, these are not the right reasons for the case of the Czech Republic. Domestic policies are considered as credible and the economic environment is stable. Yet, the high openness of the Czech economy to the European markets brings along the exchange rate risk for companies trading at least partially in the euro. Some of these companies may then prefer to conduct their transactions with domestic suppliers (residents) also in the euro for the sake of avoiding the foreign exchange risk. This de facto spontaneous euroization may then, depending on its degree, inhibit the effectiveness of monetary policy in influencing the domestic economy. It can also lead to distortion in various measures of macroeconomic activity, making the formulation of macroeconomic policy more difficult, and it can adversely affect the net foreign exchange risk exposure of a country.

\section{The Impact of Euroization on Monetary Policy}

Due to the changes in the transmission mechanism of a gradually euroizing economy the ability of monetary policy to influence the domestic economy is indisputably affected. Although the basic view of the transmission mechanism may remain the same ${ }^{4}$ ) the increasing use of the euro by domestic households and firms may decrease its importance in terms of transmitting policy changes to the economy. This may happen along the two most important transmission channels: the interest rate and the exchange rate channel. Spontaneous euroisation may also, somewhat counter-intuitively, increase the overall net foreign exchange risk exposure of a country.

\section{1 Interest Rate Channel}

Starting with the interest rate channel, we have to distinguish between the impact of monetary policy on households and on the corporate sector. In the case of households, we have to mention several critical points that may lead to a constrained ability of monetary policy to affect the behaviour of domestic households. These are receiving the incomes in the euro; saving in the euro; borrowing in the euro, and last but not least actually thinking in terms of the euro units.

The last point reflects the fact that the transmission mechanism of monetary policy is based on subjective perception of the households about a difference between the actual level of the interest rates and the equilibrium (normal) level of the interest rates, both adjusted for inflation expectations. For precise description of this mechanism see Woodford (2003) or Walsh (2003). Unless households undertake their internal decisions in the euro units, domestic monetary policy will continue to influence their behaviour. As the internal deliberations of households are unobservable, the only possible way we can follow are the three above-mentioned points. So we can only ask if the households receive their incomes in the euro, save and borrow in the euro. Bearing in mind that the households' consumption represents the biggest part of GDP, it means that if there is no observable increase in the euro saving and borrowing among households, the main part of the interest rate channel remains working.

In the case of firms, the situation is similar. Just the incentives to think and operate in the euro units are stronger because of the fact that many firms trade interna-

4) For basic view on the transmission mechanism under the inflation targeting regime see Mahadeva and Sinclair (2001). 
tionally and receive a certain part of their revenues in the euro. The constraint on the domestic monetary policy starts with the effort of these firms to transfer the payment for their inputs into euro units. If they do so, additional firms will have to face the euro incomes and will be pushed to do the same and also transfer their inputs into the euro units. This would continue over and over again and as a result firms with revenues and costs in the euro will tend to observe variables, relevant from the monetary policy perspective, connected with the euro currency. On the other hand, bearing in mind that as long as majority of firms' employees and owners are residents, the wages and salaries will be paid in domestic currency and will continue being affected by domestic monetary policy.

\section{2 Exchange Rate Channel}

Simultaneously with the interest rate channel, the above-described processes have an impact also on the exchange rate channel. ${ }^{5)}$ Using the euro as an accounting unit weakens the role of the exchange rates in firms' decisions on production and investment. However, probably more than in the case of the interest rate channel, weakening of the exchange rate channel is hindered by the necessity to pay wages and salaries in domestic currency. In the case of households the switch from domestic currency to the euro in their decision making would also results in no role for the exchange rate channel of policy transmission. But just thinking in the euro units is not sufficient for households to avoid the exchange rate influence. The necessary condition for households is to face also the domestic prices in the euro. This is identical to the firms' cost problem. With domestic prices expressed in the domestic currency, the movements of the exchange rate can still result in a change of the relative prices and affect the households' decision making process.

Apart from the obvious effects spontaneous euroization may have on the transmission of monetary policy, there may have an important impact on the overall net foreign exchange risk in the economy. The gradual transfer of the foreign exchange risk $^{6)}$ that comes with currency mismatch of revenues and costs, will likely result in smaller companies (suppliers) bearing more foreign exchange risk than if such a transfer did not take place. Since hedging entails some fixed costs, the relative cost of hedging rises for companies with smaller revenues. As a result the small companies can be forced either to decrease their profit margins or to hold the exchange rate risk without hedging. Both ways hamper the development of smaller companies and as such the country's overall production capacity. If the spontaneous euroization grows in scope large enough, the described process of risk transfer to smaller companies may be the reason for speeding up official euroization or euro-adoption.

\section{Degree of Euroization in the Czech Republic}

Induced changes in the transmission mechanism are connected with a switch of domestic households and enterprises from using the domestic currency to the euro in their transactions. However, the decision process behind this switch that is undertaken by households and enterprises is hardly observable and measurable in the reality. We can observe only the processes that we guess as peripheral expressi-

5) The impact of exchange rate on the houselds decision making is precisely described in Obstfeld and Rogoff (1999).

6) For basic explanation of the problematics of the foreign exchange rate risk see Mishkin (2001). 
ons of the internal decisions to use the domestic currency or the euro in transactions.

Since the above described problem is a matter of currency substitution, not asset substitution, measuring the degree of euroization would ideally require measuring the volume of transactions conducted in the euro among residents. As the balance of payments statistics only includes transactions with non-residents, and there is no other direct measure of transaction in the economy available, we use the deposits in the euro as an approximation. After this discussion, we will refer to a recent survey conducted by Czech National Bank's (CNB) branch offices.

\section{1 Data on Deposits}

Specifically, we calculate the ratios of the demand euro deposits over the demand deposits in the domestic currency and the euro. This, using the CNB's data set, results in the ratio of only $4 \%$ and $11 \%$ for domestic households and domestic enterprises, respectively. Calculating similar results for Hungary we receive the ratio of $16 \%$ for households and $19 \%$ for enterprises. ${ }^{7)}$ This appears to be no problem, however, especially in comparison to the country as Croatia where the ratio of foreign currency deposits to the domestic deposits and currency in the circulation is $150 \%$. The numbers for the Czech economy do not point to any major euroization going on. The development in time can be seen in Graph 1 and 2.

\section{Graph 1}

Percentage of Demand Deposits in EUR of the Total Demand Deposits for the Czech Households (in \%)

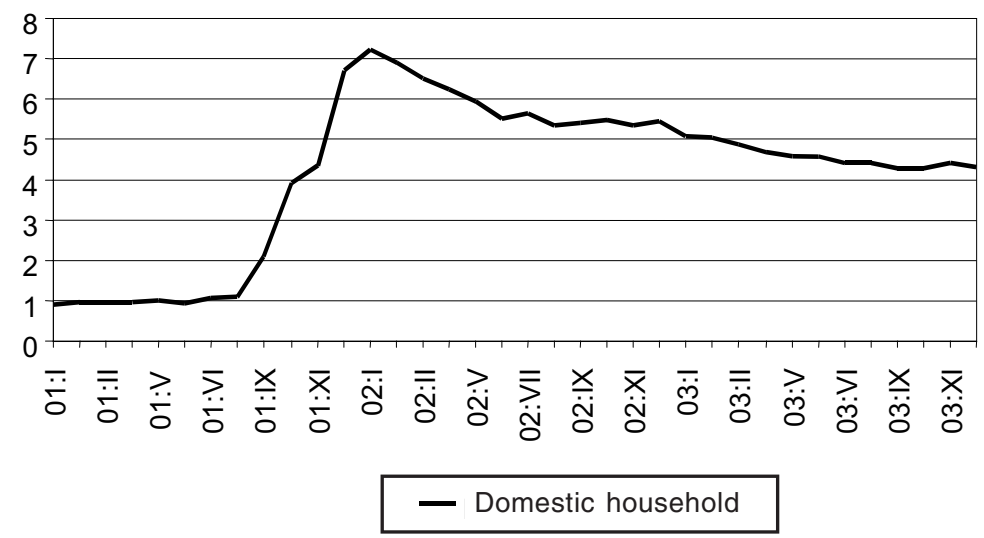

Source: CNB, 2004, own calculations.

From the graph above we can clearly see that in the case of the Czech households there was minimum percentage of the euro demand deposits of the total demand deposits till September 2001 (stabilized at the level of $1 \%$ ). During the last quarter of 2001, there was a sudden sharp increase of the euro deposits held by the Czech households as a fraction of their total demand deposits. Nevertheless, this sharp increase is easy to explain. It was clearly connected with the announced in-

7) As we do not have detailed information, the ratios are calculated using foreign currency deposits up to two years and similarly deposits up to two years denominated in domestic currency. 


\section{Graph 2}

Demand Deposits in EUR over the Total Demand Deposits of the Czech Enterprises, Considering the Annualized Monthly Change of the CZK/EUR (in \%)

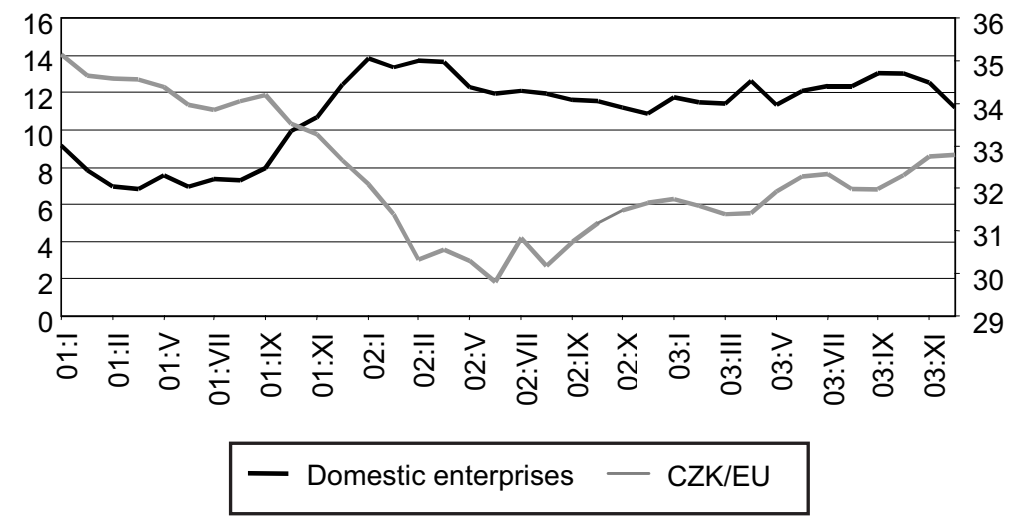

Source: CNB, Czech Statistical Office, 2004.

troduction of the euro in circulation. The easiest way for the Czech households how to cope with this announced change was to save foreign European currencies they were holding and have it changed into the euro automatically. Still, the percentage at this time was only $7 \%$ and since then it has followed a decreasing trend again. Recently the level is stabilized, slowly decreasing to the level of $4 \%$. All these factors are clearly supporting our argument that the euroization is not nowadays a problematic issue in the Czech Republic.

In Graph 2 we have analysed the situation with the Czech enterprises. Even though the level of euroization is permanently higher in this group, compared to the previous one, the trend is recently fluctuating around the level of $12 \%$ and is still decreasing. Again, for the same reasons as with households, there was a sharp increase from $8 \%$ to $14 \%$ level during the last quarter of the year 2001 but then it decreased a bit to $12 \%$ and has stayed more or less at this level. There is no visible effect of the 2002 - 2003 period of sharp koruna appreciation that could, at least in theory, motivate enterprises to switch their payments into the euro.

One of the reasons for the low degree of euroization even at times of sharp exchange rate appreciation may rest in the costs connected with euro transactions among residents. First, since such a trade relationship is considered as a foreign one, the payments must be settled on the nostro accounts at correspondent foreign banks. Second, such a foreign operation is much more time demanding, with the koruna trade the settlement is up to 24 hours but with the euro it can take even a week.

\section{22003 Czech National Bank's Survey}

Our findings can be also supported by several surveys carried out by the branches of the CNB during November 2003. ${ }^{8)}$ These surveys were conducted by six regional CNB's branches (with the exception of the branch in Prague) to find out the

8) Our thanks for providing us with the survey data and for further discussion on the issue goes to Luboš Komárek from the Czech National Bank. 
scope of the bilateral euro invoicing among domestic companies (those belonging to the region of the CNB's branch). The research was run in quite a liberal way, both with respect to the branches (that could decide on the way of conducting the research in their region) ${ }^{9)}$ and to the interviewed companies (in the sense that there were no direct questions asked). During 2004, a more in-depth systematic research was run periodically based on direct questionnaires to a wider sample of the Czech enterprises and so the information base improved over time.

The 2003 survey reveals that the companies may be divided into several groups: those with domestic ownership structure, foreign ownership structure, with position on domestic or on foreign markets. According to a group the company belongs to, we can draw some major conclusions about the volume of euro transactions. For those companies that are trading almost entirely with domestic partners there is still majority of operations run in domestic currency and there is no foresight of any change even in the near future. The fact that clearing of bank accounts among domestic companies is done in CZK only makes it too expensive and meaningless to use another currency.

On the other hand, the foreign oriented group (both export and import oriented) carries out the majority of transactions in a foreign currency. According to the surveys around $80 \%$ of transactions among both export and import oriented companies is run in the euro. Enterprises with either strong export or import only use foreign currency invoicing in $52 \%$ of their financial transactions. Domestic enterprises trading almost entirely with other domestic partners are even more domestic currency specified and use the foreign currency just in $5 \%$ to $10 \%$ of their transactions. The overall finding based on the conducted survey was that $77 \%$ of the Czech companies are sometimes facing payments in a foreign currency and for $25 \%$ of these such a payment is quite a usual means of transactions. On the other hand, the rest $23 \%$ of the Czech companies did not meet such a phenomenon at all, yet. One sixth of the interviewed companies has the impression of further increase of the euroization. The mentioned ratios are drawn in Graph 3.

Graph 3

Use of the Euro in Transactions by the Czech Enterprises (in \%)

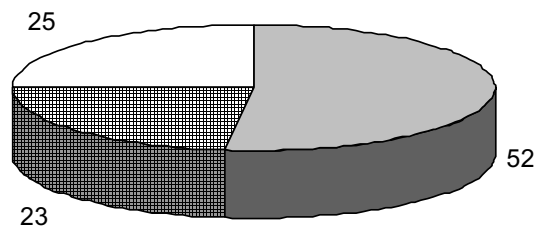

$\square$ Use the euro but not in significant number of transactions
⿴囗十 Use the euro significantly
$\square$ Use CZK only

Source: CNB Survey, 2003-2004.

9) Some of the branches were contacting companies only, some were also interviewing the Economic Chambers in their region and commercial banks' branches. Also the way of running the research was not directly specified (over telephone, in written forms, e-mail, etc.). 


\section{3 Several Survey Findings}

Southern Bohemia - the euro is used mainly by companies with foreign shares that import from their foreign suppliers and pay back in the euro. At the same time usually these big companies export majority of their products and again request the payment back in the euro. Nevertheless, still the services in these companies are paid in the domestic currency entirely. Taking into account other big companies in this region their invoicing is carried out in the euro not more than in $10 \%$. On the other hand, majority of leasing contracts on machinery is dealt in the foreign currency as a protection against the exchange rate risks. At the same time, foreign companies that have property shares in domestic companies have recently been interested in credits from domestic banks.

Eastern Bohemia - out of 24 interviewed companies, 3 did not use the euro at all, 15 only rarely and wouldn't consider euroisation to be an important issue in these days and just 6 analysed companies considered the euro transactions to be meaningful.

The analysed export oriented company is operating in the Southern Bohemian region. Because of its close connection to foreign markets, hedging against the exchange rate risk is important for them to survive in the European market conditions. The structure of their production is the following: $20 \%$ for the export in the euro, $50 \%$ for domestic trade inside the Czech Republic but in the euro and just $30 \%$ in CZK. The share of USD or other foreign currencies is not more than $5 \%$ of the total income. Since 2001, regarding the percentage of the euro encashment and the exchange rate risk when converting the euro back to CZK, the company has begun to calculate the balance in the euro. Impelling on their suppliers they have more or less forced them to trade in the euro as well and in this way they hedge against possible risks due to currency fluctuations. The euro exchange rate on incoming or outgoing payments is settled on daily basis according to the actual exchange list by the CNB. Still the salaries, both for the Czech and foreign employees, are realised entirely in CZK and the same is valid for payments of different services (mainly because domestic companies provide those).

\section{*}

This article has identified various types of euroization and their causes with a special focus on unofficial, the so-called spontaneous euroization. It was shown that gradual unofficial euroization may pose a constraint on the ability of monetary policy to influence the domestic economy. Possible constraints are stemming from weakening of both the interest rate and the exchange rate channels of the monetary policy transmission. Apart from the impact on transmission, spontaneous euroization may also lead to transferring the exchange rate risk from larger to smaller enterprises. We argue that this process could increase the overall risk in the economy and, should it become widespread, it could be an argument in favour of early official euro introduction.

After this general part, we discussed the degree of euroization in the Czech economy. The ratio of demand deposits held in the euro to the total sum of the households' demand deposits supports the idea that the unofficial euroization is not an important phenomenon among the households. The same measure for the corporate sector shows that the unofficial euroization could be more important among firms but still it is remaining at relatively low levels. The ratios are either stable or even declining and without any relation to exchange rate movements. 
The main message is that although spontaneous euroization may in principle pose important challenges for monetary policy, its present degree in the Czech Republic does not constitute any major policy problem.

\section{References}

Bratkowski, A., Rostowski, J. (2000), "Unilateral Adoption of the Euro by EU Applicant Countries: the Macroeconomic Aspects." Paper presented at the $6^{\text {th }}$ Dubrovnik Conference, 29-30 June.

CNB $(2003,2004)$, "Survey." Prague, Czech National Bank.

CSO (2004), Statistical Yearbook of the Czech Republic 2004. Prague: Czech Statistical Office.

Frait, J., Komárek, L. (2004), Rámcová analýza využití zahraničních měn v tuzemském platebním styku. Internal material Czech National Bank Prague, January 2004.

Ghosh, A., Gulde, A., Wolf, H. (2002), "Exchange Rate Regimes: Classification and Consequences." London School of Economics and Political Science Conference Paper.

Mahadeva, L., Sinclair, P. (eds.) (2001), “The Transmission Mechanism of Monetary Policy." London, Bank of England Centre for Central Banking Studies.

Mazzaferro, F., Thimann, Ch., Winkler, A. (2002), "Stabilization and Integration Views of Euroization/Dollarization Regimes: A Review of Some Specific Features." $8^{\text {th }}$ Dubrovnik Conference on "Monetary Policy and Currency Substitution in the Emerging Markets". Croatian National Bank (http:// www.hnb.hr/dub-konf/8-konferencija-radovi/mazzaferro-thimann-winkler.pdf).

Meade, E. E., Müller-Plantenberg, N., Pisani, M. (2002), "Exchange Rate Arrangements in EU Accession Countries: What Are the Options?" London, Centre for Economic Performance Occasional Paper 17.

Mishkin, F. (2001), The Economics of Money, Banking, and Financial Markets (6th ed.). Reading, MA: Addison-Wesley.

Nuti, D. M. (2002), "Costs and Benefits of Unilateral Euroization in Central Eastern Europe." Moscow, Russian-European Center for Economic Policy Research Paper.

Obstfeld, M., Rogoff, K. (1999), Foundations of International Macroeconomics. Cambridge, MA: MIT Press.

Walsh, C. E. (2003), Monetary Policy and Theory. Cambridge, MA: MIT Press.

Woodford, M. (2003), Interest and Prices. Princeton: Princeton University Press. 